\title{
The Impact of Gender on Financial Goal Setting and Planning
}

\author{
Fan Liu $^{1}$ \\ ${ }^{1}$ John L. Grove College of Business, Shippensburg University, Pennsylvania, USA \\ Correspondence: Fan Liu, John L. Grove College of Business, Shippensburg University, Pennsylvania 17257, \\ USA. Tel: 717-477-1786. E-mail: fliu@ ship.edu
}

Received: March 8, 2021

Accepted: March 20, 2021

Online Published: April 10, 2021

doi:10.5539/ijef.v13n5p36

URL: https://doi.org/10.5539/ijef.v13n5p36

\begin{abstract}
Both women and men desire to achieve their financial security. Financial planning, as a long-term method, allows us to manage certain financial aspects of our lives. However, women and men tend to have different financial behavior that may play a key role in financial planning. In this paper, we analyze the survey data collected by the Consumer Financial Protection Bureau to examine the gender effect on goal setting in financial planning. We observe that women overall tend to be more likely to set financial goals or create plans to secure the quality of life even though they are less financially knowledgeable and more economically disadvantaged in society. In particular, we identify that such gender difference is more noteworthy among working-age individuals but not among retirees. Further, we also explore how gender influences financial goal setting and planning decisions within different ethnic groups.
\end{abstract}

Keywords: financial planning, gender, goal setting, women

\section{Introduction}

Men and women both long for their financial security. Financial planning, a long-term process to wisely managing finances, fits into such desire. Goal setting as one of the key elements of financial planning gives purpose and structure to individual financial decisions. Setting financial goals such as short-term goals or long-term goals is an essential step toward being financially secure. Individuals who don't have financial plans appear to build much less wealth than those who have since lack of financial goals and plans is associated with poor saving and portfolio choice (Lusardi \& Mitchell, 2007c).

Despite the promise of better economic welfare due to more participation of women in higher education, women are generally considered to be economically disadvantaged when compared with men across all ethnic groups. It is commonly known that women earn less than men. Women overall in the United States are paid 82 cents for every dollar paid to men (Note 1). Data collected by the Federal Reserve in 2016 show that households headed by women save $\$ 17,000$ on average per year which is half of the amount saved by the households headed by men. Aside from women's unpaid labor, women are expected to live longer than men, and are therefore often responsible for saving more retirement income (Note 2). The overall lower lifetime earnings make it critically essential for women to make rational financial planning decisions from the very beginning. Then, does it mean women are assumed to be more goal driven and goal oriented when managing their finances? Do women and men share the same insight of the necessity of goal setting and planning for their sustained financial well-being? When such questions are asked, the answer often boils down to the gender effect on the financial planning.

Contemporary interest in the relationship between gender and personal finance has driven by the increased engagement of women in the financial planning decision-making process. However, to our knowledge, most studies only discuss gender differences in the field of psychology. Although some researches examine gender effect on personal financial wellbeing, the literature of gender differences in financial planning is not mature. Not much effort has been done in behavioral finance to study the gender effect on the decision-making in personal finance. This paper contributes to the literature by addressing such gap with more insights and evidence of gender effect.

The main goal of this paper is to examine whether gender does determine the goal setting in the financial planning. That is, do women tend to be more likely to have financial goals or plans than men? We discuss this question by examining the survey data from the Consumer Financial Protection Bureau (or CFPB). In 2016, CFPB designed a survey which represents the adult population in the United States to assess the individual 
financial well-being. It collected data regarding individual and household characteristics, financial assets, financial experiences and behaviors as well as financial skills and attitudes. We elicit the individual financial goal setting from the survey data and study the elements that drive the relevant financial planning decisions. We observe that female respondents in the survey are more likely to have financial goals and plans than male respondents. In addition to gender, personal traits, financial skills and financial knowledge also substantially influence the decision to have financial goals and plans. Interestingly, our results reveal that such gender effect mainly impacts working-age group. For old age group, gender does not necessarily contribute to the financial goal decisions. Moreover, when the ethnicity is controlled, we find that gender has different magnitudes of impact on financial goal setting and planning in each ethnical group. These findings are notable from the household finance perspective in which women are traditionally thought to earn less, save less, and plan less. Thus, not only women bear the cost associated with the misunderstanding of their financial behavior, society as a whole also does.

This study is unique in two ways. First, while prior research has investigated gender differences in financial knowledge of retirement planning (Lusardi \& Mitchell, 2007c; Lusardi \& Mitchell, 2008) or gender effects on the factors related to financial wellbeing (Falahati \& Sabri, 2015), this study focuses mainly on the general financial goal setting decision-making. Second, our analysis is performed on a very multi-attribute survey data. This survey data provides a sample of the major population but weighted on the region, age and race as well as a complete list of individual and household variables.

Our research contributes to the current literature by discussing the compelling effect of gender on the financial goal setting and, in turn, behavioral intention for financial planning. Findings in this paper can be helpful to those who are seeking to understand gender differences in financial decision-making and to enhance women's ability to prepare themselves for the financial realities they may face.

We review the prior literature on gender differences in Section 2. We then develop the testable hypothesis in Section 3 and describe the method and the estimation procedure in Section 4. We also discuss the results and offer conclusions in Section 5 and Section 6, respectively.

\section{Literature Review}

Gender is a social dichotomy phenomenon that exists in all societies. It is commonly known that women and man differ substantially in their skills, attitudes and behavior (Alcon, 1999). Evidence on the existence of gender differences in behavioral finance originates from the field of psychology. The general psychology literature such as Eagly (1995) contains many findings of gender effect in individual social behavior, decision-making, and personality traits. These findings partially shape the images of genders in the specific framework of finance. In consumer finance, studies have established that there exist differences in how women and men discern their financial matters. Evidence from Hira et al. (2000) reveals that it is more likely for women to create life chaos and feel dissatisfied with their current financial situation than men due to their significantly different spending behaviors.

Personal finance and family monetary practices draw great attention to gender issue in recent years. In household finance, several studies identify the impact of financial skills and financial attitudes as the key determinants of financial management (Allen et al., 2007). In addition, findings from these studies show that gender as socio-demographic factor has great influence on these determinants. For instance, Newcomb and Rabow (1999) illustrates that male family members use their financial skills and knowledge to engage into family financial decisions while female members are left out from the discussion. Lim et al. (2003) shows that different genders comprehend money in quite different way as a result of the variations in consumer socialization during childhood. In the same vein, Shim et al. (2009) and Gutter et al. (2010) confirm that differences existing in the socialization process contribute to gender differences in financial decision-making and as a result females tend to rely heavily on males to make financial decisions. Analysis of statistics related to various financial matters establish that women and men have different levels of financial skills and knowledge, with women having relatively lower levels for both. Women have generally been uninformed with lower financial information and knowledge regarding investment and insurance. This accordingly results in the fact that women perceive more financial problems in their life cycle, especially during their advanced years. Lusardi and Mitchell (2008) examines factors determining women's retirement planning. Their findings illustrate that older women have much lower levels of financial knowledge and experience, with most of them having no retirement planning. Malhotra and Witt (2010) discusses several reasons that cause women to fall behind men in their financial planning. The study suggests that women must improve their abilities to recognize the benefits of taking control of their financial future by increasing financial knowledge and skills. Stendardi (2006) reveals how men and 
women differ in investment decision-making and suggests that financial planners and advisors may tailor their methods to accommodate the gender of their customers. In addition, Grace et al. (2010) studies divergent perspectives between men and women when it comes to retirement planning through unique in-depth interviews. It indicates that men adopt an individual choice perspective assuming that retirement will be another stage in life. Meanwhile, women adopt a life course perspective viewing that outcomes as dependent on the circumstances of life. Falahati and Sabri (2015) exploits college students in Malaysia to evaluate the impact of gender on the financial wellbeing determinants. Interestingly, the findings show that gender has a considerably moderating effect on the determinants affecting college students' financial wellbeing.

Albeit prior studies conducted to assess gender effect in finance, most mainly focus on determinants related to retirement planning or financial wellbeing. Studies in the context of the goal setting and planning from financial planning perspective are still rare considering that gender differences in financial planning is a matter of interest among both academics and practitioners. Thus, the focus of this research is to examine whether gender performs a major role in financial goal setting and planning. Understanding such gender impact is particularly critical to develop policies to enhance the financial circumstances of women through improvement of efficient financial planning.

\section{Hypotheses}

Women are known to make less and live longer than men, which makes financial planning a daunting task for many women. Malhotra and Witt (2010) points out that women face more obstacles than men in financial planning. Their saving and spending behaviors are greatly impacted by the wage gap. Moreover, prior studies have well documented the relatively lower level of women's financial literacy. They have shown that financial knowledge and planning are evidently correlated. Individuals who demonstrate higher financial knowledge and skills are highly possible to plan and be successful planners (Alcon, 1999). In particular, lack of knowledge about financial planning makes it extremely hard for women to manage the financial planning challenger. Lusardi and Mitchell (2008) discusses how low levels of financial literacy among old women lead to their poor retirement planning. Dvorak and Hanley (2010) studies how financial literacy with demographic information is related to the understanding of financial plans. The results of this research suggest that financial education should be specially designed to target at women who have lower levels of financial literacy compared with men in the population to help them become financially independent. Chen and Volpe (2002) finds that women overall have less knowledge about personal finance topics before and after the effects of other variables are controlled in the sample. They observe that women appear to be less enthusiastic and willing than men to learn about personal finance topics. Under such framework, women are less likely to participate in the decision-making of financial planning which includes financial goal setting and planning.

While many studies have established the evident differences between the financial knowledge and financial behaviors of men and women, there are several studies in the literature find the inconsistent gender effect across different dimensions. For instance, Fitzsimmons and Wakita (1993) find that there is no difference between women and men how they set expectations of future financial conditions. Samples of college students used in Falahati and Sabri (2015) indicate that gender does influence factors related to financial wellbeing but with surprisingly moderating effect. Zweig (2009) states that women's attitudes towards money boost their decisions to set financial plans and retirement objectives. After financial plans are initiated, women are much more patient to follow in the procedures than men. Garrison and Gutter (2010) find that women have unexpectedly higher exposure to financial social learning opportunities across different dimensions, which allows women to improve their financial planning abilities. Thus, synthesizing such work, we propose that women should handle their finances and participate in the financial planning more actively. Specifically, this leads us to hypothesize the following:

\section{$\mathrm{H}_{1}$ : Women are more likely to have financial goals and plans than men when managing personal finance.}

If supported, this finding would signify that women rely on financial planning which involves goal setting and planning to conquer the financial disadvantages they may have to sustain their financial wellbeing in the long run.

\section{Methodology}

\subsection{Survey}

The web-based survey, known as the National Financial Well-Being Survey, was originally designed and conducted by the CFPB between October and December in 2016. The survey sample, drawn from the GfK KnowledgePanel $^{\circledR}$ (Note 3), represented nationwide U.S. households from the adult population (age 18 and 
above).

Overall, 6394 surveys were originally completed (Note 4). Variables collected through this national survey included data on individual, household and family characteristics as well as on income and employment characteristics. Besides, data on individual financial knowledge, financial skills, financial experiences and financial behaviors are also collected (Note 5).

\subsection{Instrumentation}

In this section, we discuss several important survey instruments that the variables in the model are built on.

\subsubsection{Financial Goal Setting}

To elicit individual financial goal setting behavioral intention, the survey question "Do you have a current or recent financial goal?" is adopted. The responses "No" or "Yes" collected are utilized as the dependent variable in the estimation (Note 6). One possible concern of using this specific question to draw whether respondents have financial plans and goals is that respondents might be too embarrassed to reveal their true financial details and simply answered "Yes" in the questionnaire even they have no any financial goal at all. Note that financial planning process involves managing a wide range of financial assets to achieve the financial goals, we believe that those respondents who have financial goals should also own relatively more varieties of financial assets. To ascertain the accuracy of the responses, we cross-examine different financial products owned and reported by the respondents. Table 1 summarizes the percentage of respondents who have financial goals actually own different categories of financial assets. As shown in the table, respondents who have financial goals are also more likely to be covered by life insurance and health insurance. As Lusardi and Mitchell (2007c) point out that individuals with financial goals have more likelihood to invest their money in stocks and tax-favored assets, we observe that more than two-thirds of the respondents who self-report having financial goals also self-report have checking account for cash management, 401(K)/IRA for retirement plan, stocks/bonds for investment, and education savings account for taxation plan. Thus, we believe that the survey question "Do you have a current or recent financial goal?" can be used as a sufficient instrument indicating financial planning and goal-setting preferences.

Table 1. Summary of respondents who had financial goals and financial assets

\begin{tabular}{lc}
\hline Assets & Percentage \\
\hline Checking account & $66.19 \%$ \\
Life insurance policy & $69.09 \%$ \\
Health insurance policy & $66.75 \%$ \\
$401(\mathrm{k})$ / IRA & $69.96 \%$ \\
Stocks / Bonds & $69.8 \%$ \\
Education savings account & $79.95 \%$ \\
\hline
\end{tabular}

\subsubsection{Financial Knowledge}

Financial knowledge influences financial behavior. Knoll and Houts (2012) derive psychometrically sound 20 -item financial knowledge scale and used them to analyze items from national surveys. To measure financial knowledge, we adopt Knoll and Houts financial knowledge scale score (or KH score) determined by the financial skill questions in the survey. These questions covered a wide range of basic financial concepts such as long-term return on investment, market volatility, mortgage, interest rate and benefits of diversification. The $\mathrm{KH}$ score serve as the indicator of individual's financial knowledge in the model.

\subsubsection{Financial Skills}

Financial ability is considered as the set of skills that encourages the financial behaviors. To access the individual financial skills, a list of financial skill related questions, such as "I am able to recognize a good financial investment" are presented in the survey. The responses to the general financial skill question "How would you assess your overall financial skills" are collected (Note 7) and used to elicit individual financial skills. In addition to the adoption of the responses to the general financial skill question, FS score, an item response theory (or IRT)-based scale developed by the CFPB, was also considered in the model to measure the financial skills.

\subsection{Estimation}

To exploit the gender effect on individual financial goal setting and planning, the survey response to the financial 
goals is used as the dependent variable. In additional to the gender, other potential key determinants representing individual financial skills, financial knowledge, financial planning interconnections, personal traits, and demographic info are also included as the independent variables for analysis. With the dichotomous dependent variable, a probit model is derived as:

$$
\begin{gathered}
\text { FinacialGoal }=\Phi\left(\beta_{1} \text { FinancialSkill }+\beta_{2} \text { FinancialKnowledge }+\beta_{3} \text { FinancialInstitutionCommunication }+\right. \\
\left.\beta_{4} \text { FinanicalAdvisorCommunication }+\beta_{5} \text { Age }+\beta_{6} \text { Education }+\beta_{8} \text { Gender }+\beta_{9} \text { HouseholdIncome }+\varepsilon\right)
\end{gathered}
$$

\section{Results and Robustness}

Model1 built on the full survey sample captured the impact of gender on financial goal setting. As illustrated in the Table 1, gender as well as other independent variables are all significant at the $1 \%$ level. Results from Model1 suggest that gender does have impact on financial behavior associated with the goal setting and planning. This supports our hypothesis. Compared to men, women are more likely to set goals or plans when dealing with the finances. Consistent with the prior literature, financial skill, financial knowledge and education level have considerably positive effects on having financial goals as well. In particular, personal interconnections with the financial institutions and the financial advisors boost the likelihood for individuals to have financial plans.

Table 2. Gender effect on financial goal setting with full survey sample

\begin{tabular}{lc}
\hline & Model 1 \\
Variables & Financial Goals with Full Sample \\
\hline Financial Skill & $0.162^{* * *}$ \\
Financial Knowledge (KH score) & $0.0138)$ \\
& $0.119^{* * *}$ \\
Interconnection Financial Institutions & $(0.0255)$ \\
& $0.283^{* * *}$ \\
Interconnection Financial Advisors & $(0.0445)$ \\
& $0.212^{* * *}$ \\
Age & $(0.0421)$ \\
Education & $-0.109^{* * *}$ \\
Gender & $(0.00851)$ \\
Household Income & $0.0759^{* * *}$ \\
Constant & $(0.0173)$ \\
Observations & $0.0947 * * *$ \\
\hline Note $* \mathrm{p}<0.1, * * \mathrm{p}<0.05 * * * \mathrm{p}<0.01$ and standard errors are reported in parentheses & $(0.0346)$ \\
& $0.0292^{* * *}$ \\
\end{tabular}

To understand whether such gender difference is consistent across all age group, we divide the sample of observations into two subsamples based on the age. One subsample includes respondents who are 62 and older. The other subsample includes those who are younger than 62. By using these two subsamples, we are able to observe the degree of impact of the gender on financial planning goal setting between the working-age group and the retiree group. Results of Model 2 from the table 3 demonstrates that gender still has essential impact on whether having financial goals. Women with working age are shown to be better prepared for their future with financial goals and plans than the men within the same age group. However, such prominent effect vanished when both men and women reach their retirement age as shown in model3. This finding is very interesting. Prior literature such as Lusardi and Mitchell (2008) believed that old women have undertaken no financial planning when compared to old men. However, our results illustrate that there seems to have no obvious gender effect in financial goal setting among retirees. On the other hand, gender does significantly divide in financial behavior in the younger group. For individuals with age below 62, women tend to have more likelihood to have financial plans and goals than the men within the same age group. 
Table 3. Gender effect on financial goal setting with different age groups

\begin{tabular}{|c|c|c|}
\hline Variables & $\begin{array}{c}\text { Model } 2 \\
\text { Financial Goals with Age Below } 62\end{array}$ & $\begin{array}{c}\text { Model } 3 \\
\text { Financial Goals with Age Above } 62\end{array}$ \\
\hline \multirow{2}{*}{ Financial Skill } & $0.183 * * *$ & $0.124 * * *$ \\
\hline & $(0.0171)$ & $(0.0233)$ \\
\hline \multirow[t]{2}{*}{ Financial Knowledge (KH score) } & $0.144 * * *$ & 0.0642 \\
\hline & $(0.0318)$ & $(0.0433)$ \\
\hline \multirow[t]{2}{*}{ Interconnection Financial Institutions } & $0.332 * * *$ & $0.223 * * *$ \\
\hline & $(0.0618)$ & $(0.0653)$ \\
\hline \multirow[t]{2}{*}{ Interconnection Financial Advisors } & $0.266^{* * *}$ & $0.169 * * *$ \\
\hline & $(0.0599)$ & $(0.0612)$ \\
\hline \multirow[t]{2}{*}{ Education } & $0.0673^{* * *}$ & $0.0915^{* * *}$ \\
\hline & $(0.0223)$ & $(0.0277)$ \\
\hline \multirow[t]{2}{*}{ Age } & $-0.0888 * * *$ & $-0.208^{* * *}$ \\
\hline & $(0.0174)$ & $(0.0318)$ \\
\hline \multirow[t]{2}{*}{ Gender } & $0.122 * * *$ & 0.0325 \\
\hline & $(0.0436)$ & $(0.0578)$ \\
\hline \multirow[t]{2}{*}{ Household Income } & $0.0313^{* * *}$ & 0.0183 \\
\hline & $(0.00947)$ & $(0.0132)$ \\
\hline \multirow[t]{2}{*}{ Constant } & $-0.828 * * *$ & 0.393 \\
\hline & $(0.139)$ & $(0.290)$ \\
\hline Observations & 4,095 & 2,223 \\
\hline
\end{tabular}

Note. ${ }^{*} \mathrm{p}<0.1, * * \mathrm{p}<0.05, * * * \mathrm{p}<0.01$ and standard errors are reported in parentheses.

In addition to our analysis of the gender difference in financial goal setting across age groups, we also study the gender impact on financial behavior among different racial groups. By analyzing subsamples based on the race, we are able to better perceive how gender difference affects financial planning behavior among different racial groups. Table 4 lists results of the models based on different races. It seems that only the white group as shown in Model4 displays the significant gender effect on financial goal setting. Meanwhile, individuals from the other racial groups are more influenced by their personal traits or financial skills when setting financial goals or making financial plans.

Table 4. Gender effect on financial goal setting with different racial groups

\begin{tabular}{|c|c|c|c|c|}
\hline Variables & $\begin{array}{c}\text { Model } 4 \\
\text { Financial Goals } \\
\text { with Race= White }\end{array}$ & $\begin{array}{c}\text { Model } 5 \\
\text { Financial Goals } \\
\text { with Race=Black }\end{array}$ & $\begin{array}{c}\text { Model } 6 \\
\text { Financial Goals } \\
\text { with Race=Others }\end{array}$ & $\begin{array}{c}\text { Model } 7 \\
\text { Financial Goals with } \\
\text { Race=Hispanic }\end{array}$ \\
\hline Financial Skill & $\begin{array}{c}0.150 * * * \\
(0.0173)\end{array}$ & $\begin{array}{c}0.138 * * * \\
(0.0376)\end{array}$ & $\begin{array}{l}0.135 * * \\
(0.0633)\end{array}$ & $\begin{array}{c}0.217 * * * \\
(0.0336)\end{array}$ \\
\hline Financial Knowledge (KH score) & $\begin{array}{c}0.128 * * * \\
(0.0311)\end{array}$ & $\begin{array}{c}0.140 * \\
(0.0825)\end{array}$ & $\begin{array}{l}0.0938 \\
(0.102)\end{array}$ & $\begin{array}{c}0.213^{* * * *} \\
(0.0704)\end{array}$ \\
\hline Interconnection Financial Institutions & $\begin{array}{c}0.304 * * * \\
(0.0518)\end{array}$ & $\begin{array}{c}0.156 \\
(0.141)\end{array}$ & $\begin{array}{c}0.223 \\
(0.189)\end{array}$ & $\begin{array}{l}0.244^{*} \\
(0.144)\end{array}$ \\
\hline Interconnection Financial Advisors & $\begin{array}{c}0.198 * * * \\
(0.0478)\end{array}$ & $\begin{array}{c}0.321 * * \\
(0.147)\end{array}$ & $\begin{array}{l}0.343^{*} \\
(0.198)\end{array}$ & $\begin{array}{c}0.207 \\
(0.147)\end{array}$ \\
\hline Age & $\begin{array}{c}-0.116^{* * * *} \\
(0.0100)\end{array}$ & $\begin{array}{c}-0.108^{* * *} \\
(0.0278)\end{array}$ & $\begin{array}{l}-0.0477 \\
(0.0374)\end{array}$ & $\begin{array}{c}-0.0986 * * * \\
(0.0251)\end{array}$ \\
\hline Education & $\begin{array}{c}0.0640 * * * \\
(0.0207)\end{array}$ & $\begin{array}{c}0.0295 \\
(0.0567)\end{array}$ & $\begin{array}{c}0.0872 \\
(0.0735)\end{array}$ & $\begin{array}{c}0.131 * * * \\
(0.0463)\end{array}$ \\
\hline Gender & $\begin{array}{l}0.0806 * \\
(0.0413)\end{array}$ & $\begin{array}{c}0.127 \\
(0.107)\end{array}$ & $\begin{array}{c}0.230 \\
(0.155)\end{array}$ & $\begin{array}{c}0.0971 \\
(0.0953)\end{array}$ \\
\hline Household Income & $\begin{array}{c}0.0372 * * * \\
(0.00923)\end{array}$ & $\begin{array}{c}0.0532 * * \\
(0.0237)\end{array}$ & $\begin{array}{c}0.0201 \\
(0.0331)\end{array}$ & $\begin{array}{l}-0.00428 \\
(0.0203)\end{array}$ \\
\hline Constant & $\begin{array}{c}-0.483 * * * \\
(0.127)\end{array}$ & $\begin{array}{l}-0.242 \\
(0.307)\end{array}$ & $\begin{array}{c}-0.890 * * \\
(0.446)\end{array}$ & $\begin{array}{c}-0.619 * * \\
(0.266)\end{array}$ \\
\hline Observations & 4,461 & 668 & 333 & 856 \\
\hline
\end{tabular}

Note. $* \mathrm{p}<0.1, * * \mathrm{p}<0.05, * * * \mathrm{p}<0.01$ and standard errors are reported in parentheses. 
Robustness check is also performed to ensure the consistency of the findings. Since the self-reporting general question used in the survey to assess the individual financial skills could be highly subjective and might unintentionally affect other independent variables we examined in the model, FS score was used in lieu. With full survey sample, Model 8 replicated the same significant effects we had from the Model 1. Model 9 and Model 10 used subsamples based on age group and racial group respectively. Results from both models were in line with our findings.

Table 5. Robustness check with FS score

\begin{tabular}{|c|c|c|c|}
\hline Variables & $\begin{array}{l}\text { Model } 8 \\
\text { Financial Goals with Full Sample }\end{array}$ & $\begin{array}{c}\text { Model } 9 \\
\text { Financial Goals with Age } \\
\text { Below } 62 \\
\end{array}$ & $\begin{array}{c}\text { Model } 10 \\
\text { Financial Goals with } \\
\text { Race=White }\end{array}$ \\
\hline FS score & $\begin{array}{l}0.0198 * * * \\
(0.00144)\end{array}$ & $\begin{array}{r}0.0234 * * * \\
(0.00178)\end{array}$ & $\begin{array}{l}0.0188 * * * \\
(0.00177)\end{array}$ \\
\hline Financial Knowledge (KH score) & $\begin{array}{l}0.122 * * * \\
(0.0256)\end{array}$ & $\begin{array}{l}0.143 * * * \\
(0.0320)\end{array}$ & $\begin{array}{l}0.129 * * * \\
(0.0312)\end{array}$ \\
\hline Interconnection Financial Institutions & $\begin{array}{c}0.273 * * * \\
(0.0447)\end{array}$ & $\begin{array}{l}0.312 * * * \\
(0.0623)\end{array}$ & $\begin{array}{c}0.296 * * * \\
(0.0519)\end{array}$ \\
\hline Interconnection Financial Advisors & $\begin{array}{l}0.191 * * * \\
(0.0423)\end{array}$ & $\begin{array}{l}0.236^{* * *} \\
(0.0603)\end{array}$ & $\begin{array}{l}0.177 * * * \\
(0.0480)\end{array}$ \\
\hline Age & $\begin{array}{l}-0.109 * * * \\
(0.00854)\end{array}$ & $\begin{array}{c}-0.0777 * * * \\
(0.0175)\end{array}$ & $\begin{array}{l}-0.115^{* * *} \\
(0.0100)\end{array}$ \\
\hline Education & $\begin{array}{c}0.0776^{* * * *} \\
(0.0173)\end{array}$ & $\begin{array}{c}0.0736^{* * * *} \\
(0.0224)\end{array}$ & $\begin{array}{c}0.0620 * * * \\
(0.0208)\end{array}$ \\
\hline Gender & $\begin{array}{l}0.0831 * * \\
(0.0347)\end{array}$ & $\begin{array}{l}0.113 * * * \\
(0.0438)\end{array}$ & $\begin{array}{l}0.0696^{*} \\
(0.0413)\end{array}$ \\
\hline Household Income & $\begin{array}{l}0.0277 * * * \\
(0.00762)\end{array}$ & $\begin{array}{l}0.0295 * * * \\
(0.00952)\end{array}$ & $\begin{array}{l}0.0346 * * * \\
(0.00926)\end{array}$ \\
\hline Constant & $\begin{array}{c}-0.841^{* * * *} \\
(0.114)\end{array}$ & $\begin{array}{c}-1.168 * * * \\
(0.146)\end{array}$ & $\begin{array}{c}-0.685^{* * *} \\
(0.130)\end{array}$ \\
\hline Observations & 6,318 & 4,095 & 4,461 \\
\hline
\end{tabular}

\section{Conclusions}

Women are portraited as the one that are less knowledgeable about finances and are considered to be economically disadvantaged in many studies. Nevertheless, due to the reality that women generally have longer life expectancy than men, financial planning becomes critically urgent for women. One interesting and essential question related to the financial planning is whether gender has impact on financial goal setting and planning. That is, whether women are more likely to set financial goals and make financial plans when managing their personal finance.

In this paper, a nationwide survey data was used to examine the gender effect on financial goal setting preference. Our results demonstrate that women in general are more likely to have financial goals when compared with men. In particular, when the analysis is performed across all age groups, working-age women tend to be more driven to have financial plans and goals than those retirees. Furthermore, different degree of gender effect is also observed among different racial groups.

This study contributes to the existing literature by examine the prominent gender effect on goal setting in financial planning. Understanding the impact of gender on financial goal setting and planning empowers women's engagement with finances and their abilities to sustain control of their financial lives over the long term. For women, information, education, trust and confidence are the necessary precursors to successful personal financial management. Meanwhile, women have been historically underserved in the financial industry. Meeting these financial needs for women urges financial services industry to reconsider outmoded financial tools designed for a universal customer but fail to accommodate women. This paper may shed light on the importance of the knowledge about gender effect on financial goal setting to provide useful general guidelines for financial planners to consider when working with female customers. 


\section{References}

Alcon, A. (1999). Financial planning and the mature woman. Journal of Financial Planning, 12(2), 82.

Allen, M. W., Edwards, R., Hayhoe, C. R., \& Leach, L. (2007). Imagined interactions, family money management patterns and coalitions, and attitudes toward money and credit. Journal of Family and Economic Issues, 28(1), 3-22. https://doi.org/10.1007/s10834-006-9048-1

Chen, H., \& Volpe, R. P. (2002). Gender differences in personal financial literacy among college students. Financial Services Review, 11(3), 289-307.

Dvorak, T., \& Hanley, H. (2010). Financial literacy and the design of retirement plans. The Journal of Socio-Economics, 39(6), 645-652. https://doi.org/10.1016/j.socec.2010.06.013

Eagly, A. H. (1995). The science and politics of comparing women and men. American Psychologist, 50(3), 145. https://doi.org/10.1037/0003-066X.50.3.145

Falahati, L., \& Sabri, M. F. (2015). An exploratory study of personal financial wellbeing determinants: Examining the moderating effect of gender. Asian Social Science, 11(4), 33. https://doi.org/10.5539/ass.v11n4p33

Garrison, S. T., \& Gutter, M. (2010). 2010 outstanding AFCPE® conference paper: gender differences in financial socialization and willingness to take financial risks. Journal of Financial Counseling and Planning, 21(2).

Gutter, M. S., Garrison, S., \& Copur, Z. (2010). Social learning opportunities and the financial behaviors of college students. Family and Consumer Sciences Research Journal, 38(4), 387-404. https://doi.org/10.1111/j.1552-3934.2010.00034.x

Hira, T. K., \& Mugenda, O. (2000). Gender differences in financial perceptions, behaviors and satisfaction. Journal of Financial Planning-Denver, 13(2), 86-93.

Knoll, M. A., \& Houts, C. R. (2012). The financial knowledge scale: An application of item response theory to the assessment of financial literacy. Journal of Consumer Affairs, 46(3), 381-410. https://doi.org/10.1111/j.1745-6606.2012.01241.x

Lim, V. K., Teo, T. S., \& Loo, G. L. (2003). Sex, financial hardship and locus of control: an empirical study of attitudes towards money among Singaporean Chinese. Personality and Individual Differences, 34(3), 411-429. https://doi.org/10.1016/S0191-8869(02)00063-6

Lusardi, A., \& Mitchell, O. S. (2008). Planning and financial literacy: How do women fare? American Economic Review, 98(2), 413-17. https://doi.org/10.1257/aer.98.2.413

Lusardi, A., \& Mitchelli, O. S. (2007). Financial literacy and retirement preparedness: Evidence and implications for financial education. Business Economics, 42(1), 35-44. https://doi.org/10.2145/20070104

Malhotra, N., \& Witt, M. (2010). Determinants of financial and retirement planning: A female perspective. Journal of Business \& Economics Research (JBER), 8(6). https://doi.org/10.19030/jber.v8i6.732

Newcomb, M. D., \& Rabow, J. (1999). Gender, Socialization, and Money 1. Journal of Applied Social Psychology, 29(4), 852-869. https://doi.org/10.1111/j.1559-1816.1999.tb02029.x

Organisation de coopération et de développement économiques. (2014). PISA 2012 Results: Students and Money (Volume VI): Financial Literacy Skills for the 21st Century. oeCd publishing.

Shim, S., Xiao, J. J., Barber, B. L., \& Lyons, A. C. (2009). Pathways to life success: A conceptual model of financial well-being for young adults. Journal of Applied Developmental Psychology, 30(6), 708-723. https://doi.org/10.1016/j.appdev.2009.02.003

Stendardi, E. J., Graham, J. F., \& O'Reilly, M. (2006). The impact of gender on the personal financial planning process. Humanomics. https://doi.org/10.1108/08288660610710746

Zweig, J. (2009, May 9). For Mother's Day, give her reins to the portfolio. The Wall Street Journal, p. B1. https://www.wsj.com/articles/SB124181915279001967

\section{Notes}

Note 1 . See American's Women and the Wage Gap survey details at https://www.nationalpartnership.org/our-work/resources/economic-justice/fair-pay/americas-women-and-the-wa 
ge-gap.pdf

Note 2. See 2017 National Vital Statistics Report: https://www.cdc.gov/nchs/data/nvsr/nvsr68/nvsr68_07-508.pdf Note 3. The GfK panel, a probability-based non-volunteer Internet panel, has about 55,000 U.S. panel members.

Note 4. After data cleaning steps, 76 observations were removed. See National Financial Well-Being Survey: Public Use File User's Guide.

Note 5. A complete list of variables is available from the CFPB's Public User File Codebook.

Note 6. The response "Yes" was coded as 1 and the response "No" as 0 in the Stata for economic analysis.

Note 7. Responses were scaled from "1 Very low" to "7 Very high".

\section{Copyrights}

Copyright for this article is retained by the author(s), with first publication rights granted to the journal.

This is an open-access article distributed under the terms and conditions of the Creative Commons Attribution license (http://creativecommons.org/licenses/by/4.0/). 